\title{
भूपि शेरचनको हामी कवितामा संसक्ति व्यवस्था
}

\author{
अनिल अधिकारी ${ }^{9}$ तथा रमेश ओभा ${ }^{2}$ \\ ${ }^{9}$ मुख्य लेखक \\ उपप्राध्यापक \\ नेपाली विभाग, महेन्द्र मोरङ आदर्श बहुमुखी क्याम्पस, विराटनगर, त्रिभुवन विश्वविद्यालय, नेपाल \\ aniladhikaribhojpur@gmail.com \\ २सहायक लेखक \\ शिक्षण सहायक \\ नेपाली विभाग, एभरेस्ट एजुकेसनल फाउन्डेसन, विराटनगर, त्रिभुवन विश्वविद्यालय, नेपाल \\ ojharamesh30@gmail.com
}

DOI: https://doi.org/10.3126/dristikon.v11i1.39163

\begin{abstract}
लेखसार
प्रस्तुत अध्ययनमा कवि भूपि शेरचनद्वारा लिखित 'हामी' कविताको संसक्ति व्यवस्थाको अध्ययन गरिएको छ। यस अध्ययनको पूर्णताका लागि सङ्कथन अध्ययनभित्र संसक्ति व्यवस्थालाई सैद्धान्तिक पर्याधारका रूपमा प्रयोग गरिएको छ। मूल समस्या र शोधयप्रश्नको समाधान गर्न लागि गुणात्मक अनुसन्धान र पाठ विश्लेषण विधिको प्रयोग गरिएको प्रस्तुत अध्ययनमा हामी नेपालीको समकालीन पराधीन सोच र अभिवृत्तिलाई प्रस्तुत गर्ने कममा आएका विभिन्न सन्दर्भको संयोजनबाट सुसम्बद्ध पाठसम्बद्ध पक्षको विवेचना गरिएको छ। संसक्ति सङ्कथन अध्ययन अन्तर्गतको पाठविश्लेषण गर्ने प्रतिमान हो भने यसका व्याकरणिक र कोशीय भेद रहेका छन् । संसक्तिले भाषालाई केन्द्रविन्दुमा राखी पाठमा अवशिष्ट परिवेश, सन्दर्भहरूको अन्वयवाट पाठगत सुसम्बद्धताको खोजी गर्दछ । यस अध्ययनमा व्याकरणिक र कोशीय प्रतिमानका आधारमा कविताको विश्लेषण गरिएको छ। समकालीन परिवेशभित्र नेपाली मानसिकतामा स्थापित रहेको पराधीन सोच र अकर्मण्य अभिवृत्तिद्योतक मूलसन्दर्भसंग सम्बन्धित विभिन्न सहायक सन्दर्भको सृजना गरी संसक्ति सम्बद्धता सृजना भएको तथ्यलाई कवितामा प्रयोग भएका व्याकरणिक र कोशीय संसक्तिका रूपमा प्रयोग भएका एकाइले पाठका सन्दर्भ शृड्खखलालाई एकान्वित तुल्याई संरचनागत सुसम्बद्धता सृजना गरी सड्गठित पाठको निर्माण गरेका छन् भने सड्कथनभित्र आएका विविध आर्थीसंरचना भाएका शब्दश्ड़खलाले कविताका भाव, अर्थ, परिवेश र सन्दर्भलाई एकत्वपूर्ण प्रवाहमा जोडी सुगठित पाठ निर्माण गरेको निष्कर्ष निकालिएको छ।
\end{abstract}

शब्दकुज्जी : सड्कथन, संसक्ति, निदर्शन, प्रतिस्थापन, पुनरावृत्ति, शब्दजोडा, शब्दशृड्खला

\section{विषयपरिचय}

आधुनिक भाषाविज्ञानले वाक्यभन्दा माथिल्ला भाषिक एकाइमा रहेका भाषिक प्रकार्यको अध्ययन गर्ने पद्दतिका रूपमा सड्कथन अध्ययनको सिद्धान्त ल्याएपछि भाषिक प्रकार्यका आधारमा संरचना (सङ्कथन/कृति)को विश्लेषण गर्ने प्रतिमानका रूपमा संसक्तिको अवधारणा विकास भएको हो। संसक्तिले पाठमा रहेका व्याकरणिक तथा शाब्दी 
घटकको अन्वयबाट सृजित सन्दर्भबाट एकान्विति सृजना भई संगठित र सुसम्बद्ध पाठको निर्माण हुने प्रक्रियाको खोजी गर्दछ। संसक्ति मौखिक, लिखित र जुनसुकै आयाम भएका पाठमा अवशिष्ट व्याकरणिक तथा शाब्दी घटकका आधारमा उक्त रचनाको संगठन र सम्बद्धताका माध्यमबाट पाठमा विद्यमान अर्थको एकान्विति खोज्ने पद्दतिका रूपमा स्थापित भएको छ। यस अध्ययनमा संसक्ति सिद्धान्त र यसका कृतिविश्लेषणका प्रतिमानका आधारमा भूपि शेरचनको हामी कवितामा संसक्ति व्यवस्थाको विश्लेषण गरिएको छ। 'रूपरेखा' (२०१७)मा प्रथमपटक प्रकाशित रही घुन्ने मेचमाथि अन्धो मान्छे (२०२६) कविता सड्ग्रहमा सड्ग्रृहीत भई पुनर्प्रकाशित यस कविताका स्रष्टा शेरचन (१९९२- २०४६)का नयाँ भयाउरे (२०१०), निर्कर (२०१५), घुम्ने मेचमाथि अन्धो मान्छे ( २०२६) कवितासड्ग्रहका अतिरिक्त विभिन्न पत्रपत्रिकामा फुटकर रचनाहरू प्रकाशित भएका छन् ।

संसक्तिले पाठमा अवशिष्ट विविध सन्दर्भलाई एक निरन्तर प्रवाहमा जोडी पाठको निर्माण प्रक्रियालाई एकरूपता प्रदान गरेको हुन्छ। सङ्कथन अध्ययनअन्तर्गतको समालोचना पद्धतिका रूपमा रहेको संसक्ति व्यवस्थाले पाठ कसरी सुगठित, संगठित र सुसम्बद्ध पाठका रूपमा संरचित रहेको छ ? पाठमा आएका विविध सन्दर्भको समायोजनका लागि संसक्तिले के कसरी भूमिका खेलेको छ ? भन्ने पक्षको अध्ययन गरी पाठको शृड्खलित अन्वयको खोजी गर्दछ। संसक्तिअन्तर्गत पाठमा रहेका व्याकरणिक घटक (निदर्शन, प्रतिस्थापन लोप र संयोजन तथा शाब्दी घटकको पुनरावृत्ति, पर्यायता, विपरीतार्थता, अधिकार्थता, शब्दजोडा र शब्दशृड्खलाले सृजना गर्ने सन्दर्भ र आर्थी सम्बन्धबीच संसक्ति सम्बन्ध निर्माण भई सुसम्बद्ध र संगठित पाठको निर्माण हुन्छ भन्ने पक्षका आधारमा पाठगत अर्थको खोजी गरिन्छ। प्रस्तुत अध्ययनमा व्याकरणिक र कोशीय एकाइले हामी कविताको पहिलो अनुच्छेददेखि अन्तिम अनुच्छेदसम्मका भएको भावप्रवाह र संरचनाका माध्यमबाट सशक्त र संसक्त पाठमा रूपान्तरण गरेका पक्षलाई संसक्ति व्यवस्थाको सैद्धान्तिक प्रतिमानका आधारमा विश्लेषण गरिएको छ।

\section{समस्याकथन}

प्रस्तुत अध्ययनको मुख्य समस्या भूपि शेरचनको हामी कवितामा संसक्ति व्यवस्थाको अध्ययन रहेको छ। प्रस्तुत मुख्य समस्यासँग सम्बन्धित अन्य शोध्यप्रश्नलाई निम्नानुसार प्रस्तुत गरिएको छ :

क. हामी कवितामा निदर्शन र प्रतिस्थापक लोप, र संयोजनले कसरी संसक्ति सम्बद्धता स्थापित गरेका छन् ?

ख. पुनरावृत्ति, पर्यायता र शब्दशृड्खलाले कसरी पाठगत एकत्वलाई संसक्त तुल्याएको छ ?

\section{उद्देश्य}

उपर्युक्त मूलसमस्या र शोध्यप्रश्नका आधारमा हामी कविताको संसक्ति व्यवस्था र पाठगत सुसम्बद्धता खोजी गर्नु यस अध्ययनको उद्देश्य रहेको छ।

\section{शोधविधि तथा सामग्री}

प्रस्तुत अध्ययनको समस्यासित सम्बन्धित सामग्रीहरूको सड्कलन प्राथमिक र द्वितीयक स्रोतबाट गरिएको छ। प्राथमिक स्रोतको सामग्रीको रूपमा भूपि शेरचनको हामी कविता रहेको छ। द्वितीयक सामग्रीको रूपमा आधारभूत सैद्धान्तिक सामग्रीका लागि विभिन्न अनुसन्धानात्मक ग्रन्थ तथा लेखहरू रहेका छन् । सामग्री विश्लेषणका लागि गुणात्मक अनुसन्धान र पाठ विश्लेषण ढाँचालाई उपयोग गरिएको छ। 
सड्कथन अध्ययनमा कथ्य, साड्केतिक तथा लेख्यभाषामा प्रयोगमा आएको भाषिक स्वरूपका साथै भाषिक प्रयुक्तिहरूको समायोजन कसरी भएको छ भन्ने पक्षको अध्ययन गरिन्छ। पाठमा अवशिष्ठ अर्थको खोजी गर्दा पाठभित्र रहेका संसक्ति सम्बन्धलाई पहिचान गरी भाषिक एकाइलाई परस्परमा अन्तरसम्बद्ध तुल्याउन संसक्तिको भूमिका खोजी गरिन्छ। संसक्तिलाई ह्यालिडे र हसनले यसप्रकार परिभाषित गरेका छन् - संसक्ति भाषिक व्यवस्थाको एक अभिन्न अड्ग हो जसले भाषिक एकाइका बीच अन्तरसम्बन्ध स्थापित गरी पाठमा रहेको भाषा, भाव र वैचारिक एकत्वलाई अन्वय गराउन अहम् भूमिका खेल्दछ (१९७६ : ४)। संसक्तिले पाठमा आएका एकाइलाई निश्चित श्रृड्खलामा आबद्ध गरेको हुन्छ। पाठमा रहेका भाषिक एकाइबीच तार्किक सम्बन्ध स्थापित गर्न स्रष्टाले विभिन्न भाषिक एकाइको प्रयोग गरेको हुन्छ। तिनै एकाइको पारस्परिक संयोजनबाट एकत्वपूर्ण, ससुसम्बद्ध र सड्गठठित पाठको निर्माण हुनपुगदछ।

देवीप्रसाद गौतमले संसक्तिलाई परिभाषित गर्दे भनेका छन् - पाठभित्र आउने वाक्यहरूमा भावप्रवाह सिर्जना गर्ने विशिष्ट ढाँचाका रूपमा संसक्ति रहेको हुन्छ र यसले पाठभित्रका संवाद, मनोवाद, अनुच्छेद, वाक्य, उपवाक्य, पदावली, पद, आदिलाई सुसड्गठित बनाउँछ। संसक्ति प्रक्रिया त्यस्तो रसायन हो जसले कुनै पाठभित्रका सड्कथनका एकाइहरूलाई एकताबद्ध गर्दछ, सुसड्गठठित बनाउँछ। २०६६ : पै७४)।

संसक्तिले पाठमा प्रयुक्त भाषिक एकाइहरूले प्रदान गर्ने अर्थलाई सुसम्बद्ध सड्गठित गरी पाठमा भावगत एकत्व कायम गरेको हुन्छ।

\section{पाठ-विश्लेषणका प्रतिमान}

संसक्ति व्यवस्थाभित्र व्याकरणिक संसक्तिको विश्लेषण गर्दा निदर्शन (सन्दर्भन), सार्वनामीकरण, प्रतिस्थापन, लोप र संयोजनले पाठमा कसरी एकान्विति सृजना गरेको छ भन्ने पक्षको खोजी गरिन्छ। ह्यालिडे र हसनले व्याकरणिक संसक्तिलाई निदर्शन, सार्वनामीकरण, प्रतिस्थापन, लोप र संयोजन जस्ता पाँचप्रकारमा वर्गीकरण गरेका छन् १९७६: ४)। पाठभित्र रहेका वाक्यहरूको अर्थगत अन्तरसम्बन्धलाई बुकाउँदा आउने पद/पदावलीले पाठमा अवशिष्ट सूचना र अर्थलाई सुसड्गठित बनाउने संसक्तिलाई व्याकरिणक संसक्ति भनिन्छ। यसमा निदर्शन, प्रतिस्थापन, लोप, संयोजन जस्ता प्रतिमानले पाठमा आएका वाक्यहरूलाई पूर्वसन्दर्भ वा पश्चसन्दर्भसँग सम्बद्ध गराएका हुन्छन् । संसक्ति व्यवस्थाभित्र व्याकरणिक संसक्तिअन्तर्गत निदर्शनको भूमिका अहम् रहेको छ। पाठमा अवशिष्ट सन्दर्भको प्रतिनिधित्व गर्ने यस एकाइले सड्कथनमा रहेका सूचनालाई निर्देश गर्ने हुनाले निदर्शन तथा सन्दर्भको सड्केत गर्ने हुनाले सन्दर्भन भनिन्छ। "कुनै विषयको निश्चित सत्ता वा स्थितिलाई सूचित गरिने कार्य निदर्शन हो" (२०६६ : प७७६)। निदर्शन (रेफरेन्स) पाठमा फरक सन्दर्भमा फरक ढड्गले आउनसक्छ। यसलाई पाठमा रहेको पूर्वापर सन्दर्भका आधारमा निदर्शन विन्दु पहिचान गर्न सकिन्छ। निदर्शनले सूचनालाई निरन्तर प्रवाहित गरेको हुन्छ। यसमा वक्ताले सूचित गर्न चाहेको व्यक्ति, विषय र स्थानलाई निदर्शन बिन्दु (रेफरेन्स प्वाइन्ट) र यसलाई बुभाउने भाषिक कोटि सन्दर्भ सर्वनामका रूपमा आएका हुन्छन् । निदर्शनले पाठभित्र र पाठबाहिर रहेका सूचनालाई सन्दर्भीकृत गरी पाठलाई संसक्त तुल्याउने गर्दछ।

प्रतिस्थापक एकाइले सड्कथनमा आएका सन्दर्भ, कार्यात्मक आयाम र कथनले सङ्केत गरेका सबै पक्षलाई विस्थापित गरी पाठगत एकान्विति निर्माण गर्न आवश्यक रहेका पूर्वसन्दर्भलाई पश्च सन्दर्भसँग जोडी एकैप्रकारको सूचना प्रवाह गर्नका लागि महत्त्वपूर्ण भूमिका निर्वाह गरेको हुन्छ। "प्रतिस्थापनबाट कथनमा सड्क्षिप्तता मात्र 
नआई एक वाक्य र अर्को वाक्यका बीचमा अभिव्यक्तिगत अन्तर्सड्गतिको सृजना भई सड्कथन सबलीकृत र संसक्तसमेत हुन्छ” (प७७)। सड्कथन संरचनामा आएको सिड्गो कथनको आवृत्तिका स्थानमा कथनलाई अभिव्यक्त गर्ने सड्क्षिप्त रूपको प्रयोग गरी सङ्कथनका जटिल वाक्यभित्रका पदावली, उपवाक्य, वाक्य, एकभन्दा बढ़ी वाक्यको संरचना लुप्त नभई सड्कथनको सिड्गो वाक्य/अनुच्छेद नै प्रतिस्थापन हुने गर्दछ। संसक्तिअन्तर्गतको लोपले सृजन प्रक्रियामा भौतिक उपस्थिति नरहेका एकाइले पाठगत अभिवृत्तिलाई अपूर्ण नतुल्याई लोप अवस्थामै संसक्ति स्थापना गरेको हुन्छन् । गौतमले सड्कथनमा उपवाक्यात्मक संरचनाभित्र आएका नामिक र क्रियापदको पुनरावृत्तिलाई रोक्न अध्याहारबाट अर्थसड्गति स्थापित हुने स्थितिमा दोहोरिएका पद/पदावलीको अर्थग्रहण गर्ने प्रक्रियालाई लोप भनेका छन् (प७६)। लोप प्रक्रियाअन्तर्गत कर्ता, कर्म, पूरकका रूपमा प्रयोग हुने नामिक पद र सहायक क्रिया अधिकतर लोप हुने गर्दछन् भने लोप प्रक्रियामा पूर्वपर प्रयोग भएका शब्दको अर्थ सम्बन्ध रहिरहने अवस्थामा यस प्रक्रियाको अवलम्बन हुने गर्दछ। सङ्कथनपरक अभिव्यक्तिलाई संसक्त र सम्बद्ध गराउने अर्को व्याकरिणक संसक्ति संयोजन रहेको छ। ह्यालिडे र हसनले यसलाई योगात्मक, समायोजनमूलक, कारणात्मक र समयगत गरी चार प्रकारमा वर्गीकरण गरेका छन् (सन् १९७६ : २३०)। गौतमले संसक्ति व्यवस्थामा संयोजनअन्तर्गत सत्र प्रकारका संयोजकले फरक पृष्ठभूमि रहेका सन्दर्भलाई संयोजन गरी पाठगत सुसम्बद्धता सृजना हुने धारणा राखेका छन् (५ॅ२)। संयोजनले पाठमा रहेका आर्थी सूचनालाई परस्परमा सम्पृक्त गराई पाठभित्रका व्याकरणिक, आर्थी र सन्दर्भसूचक एकाइलाई सड्गठठित गरेको हुन्छ।

कोशीय संसक्तिले पाठमा आएका विविधतापूर्ण आर्थीसूचनालाई सड्केत गर्ने शब्दसँग सम्बन्धित पक्षको अध्ययन गर्दछ। यसले पाठमा रहेका शब्दले कसरी सन्दर्भ, अर्थ र सूचना प्रवाहलाई एकरूपता प्रदान गरी सुसम्बद्ध पाठ निर्माण भएको छ भन्ने भाषिक पक्षको अध्ययन गर्दछ। "पाठमा प्रयोग भएका शब्दहरूको पारस्परिक शृड्खला र शब्दसहचार्यका आधारमा सङ्कथनको अर्थ स्पष्ट हुन्छ। सड्कथनमा एकै आर्थी सम्बन्धमा उनिएका पाठगत संरचनाको खोजी भएकाले एकै प्रकृतिका शाब्दिक एकाइको शृड्खलाको खोजी हो । यसलाई कोशीय वा शाब्दिक संसक्ति भनिन्छ" (२०६६ : पै७९)। पाठमा निहित कोशीय संसक्तिको अध्ययन प्रयोगले पाठभित्र रहेको भावप्रवाह र आर्थीसम्बन्धको निर्धारणका लागि सबल र सशक्त माध्यमका रूपमा रहेको हुन्छ।

कोशीय संसक्तिले पाठमा रहेका कोशीय अर्थ दिने सबैप्रकारका शब्दका बीचको सम्बन्धका आधारमा पाठमा प्रवाहित भएको भाव, अर्थ, परिवेश र सन्दर्भबीच एकत्वपूर्ण प्रवाहमा महत्त्वपूर्ण भूमिका खेलेको हुन्छ। ह्यालिडे र हसनका अनुसार "पाठमा रहेका शब्दहरूको आर्थी सम्बन्धसँग सम्बन्धित रहेका शब्दहरूको पुनरावृत्ति, समानार्थकता, विपरीतार्थकता, अधिकार्थकता र शब्दश्ड़्खलाको पहिचान गरी तिनीहरूको पारस्पारिक सम्बन्ध र सम्बद्धताका आधारमा पाठको वास्तविक अर्थ, परिवेश र सन्दर्भको संज्ञान हुने गर्दछ” (पृ. २६४- २६४)। होएले संसक्ति एकाइको सूक्ष्म विभाजन गर्दे कोशीय संसक्तिले पाठको सड्गठित संरचनाका लागि पाठमा सरल र जटिल शाब्दिक पुनरावृत्ति, सरल र जटिल समावेशी आर्थी संरचना, प्रतिस्थापन, सहसन्दर्भ, लोप र बहुवचनात्मकता, डिक्सिस मुख्य रूपमा पाठगत सम्बद्धता सृजना गर्ने संसक्तिका रूपमा रहने तर्क गरेका छन् (१९९१: १०)। कोशीय संसक्ति पाठमा अवशिष्ट अर्थसँग सम्बन्धित हुन्छ जसले प्रत्येक कोशीय एकाइहरू एकअर्कासँग र अन्य सम्बद्धक एकाइ (कोहेसिभ डिभाइस)सँग पारस्परिक सम्बन्ध स्थापित गरेका हुन्छन् । लेखकले पाठमा आप्ना दृष्टिकोण प्रस्तुत गर्ने सन्दर्भमा पुनरावृत्ति, समावेशात्मकता, विपरीतार्थता, शब्दजोडा, शब्दशृड्खला, 
अप्रतिज्ञप्तिसूचकता जस्ता आर्थी एकाइले विचार, परिवेश, सन्दर्भ र अर्थ के-कसरी आएका छन् तथा तिनीहरूको पारस्परिक शृड्खला कसरी निर्माण भएको छ भन्ने पक्षको अध्ययन गर्दछ।

कोशीय संसक्तिअन्तर्गत शब्दको पुनरावृत्ति, विपरीतार्थता, समावेशात्मकता, अधिकार्थता, शब्दजोडा शब्दशृड्खला र अप्रतिज्ञप्तिसूचकताको अध्ययन गरिन्छ। "पुनरावृत्ति भनेको समान संरचना र अर्थ भएका शब्दको पटकपटक हुने आवृत्ति हो जसले पाठमा आउने सन्दर्भलाई परस्परमा सम्बद्ध गराई पाठको अर्थलाई नियन्त्रित र एकत्वपूर्ण बनाउन अहम् भूमिका खेल्दछ” (यादव र रेगमी, २०४९ : २७६)। तस्कानेनले पुनरावृत्तिलाई सरल र जटिल संरचनामा विभाजन गरी जटिल पुनरावृत्तिका रूपमा शब्दको संयुक्त संरचनालाई सङ्केत गरेका छन् ( २००६: ३१)। फरक अर्थ दिने शाब्दी संरचनाको निरन्तर प्रयोगले पनि पाठगत सन्दर्भले निरन्तरता पाई सुसम्बद्ध पाठ निर्माण हुने गर्दछ (२०१० : ११)। शब्दश्ड्खलाका रूपमा आउने शब्दले समानार्थक वा विपरीतार्थक स्वरूपमा आई पाठगत सन्दर्भलाई परस्परमा जोडी अर्थगत एकान्विति सृजना गर्न अहम् भूमिका खेलेका हुन्छन् । "सर्वसमावेशकारी अर्थको प्रतिनिधित्व गर्ने शब्दको सन्तुलित प्रयोगका रूपमा शब्दशृड्ख्यलाको अध्ययन संसक्ति, व्यवस्थाअन्तर्गत गरिन्छ" (प७७)। यसप्रकार कोशीय संसक्तिको अध्ययन क्षेत्रअन्तर्गत आएका प्रतिमानका रूपमा शब्दजोडा र शब्दशृड्खलाले पाठगत परिवेश, सन्दर्भ र आर्थी सुसम्बद्धता सृजना गर्न अहम्भूमिका खेलेका हुन्छन् । प्रस्तुत अध्ययनको समस्या समाधानका लागि संसक्ति व्यवस्थाले निर्धारण गरेका उपर्युक्त प्रतिमानलाई आधार बनाइएको छ। सामग्री विश्लेषणका लागि कृतिकेन्द्री अध्ययन पद्धतिका साथै वर्णनात्मक तथा विश्लेषणात्मक विधिको प्रयोग गरिएको छ।

\section{परिणाम तथा छलफल}

भूपि शेरचनको प्रस्तुत कविताको संसक्ति व्यवस्थाको अध्ययनअन्तर्गत व्याकरणिक र कोशीय संसक्ति सम्बन्धलाई निम्नानुसार तालिकामा प्रस्तुत गरिएको छ :

\begin{tabular}{|l|l|l|l|l|l|l|l|l|l|l|}
\hline अनुच्छेद / पड्तिक & निदर्शन & प्रतिस्थापन & लोप & संयोजन & पुनरावृत्ति & $\begin{array}{l}\text { समावेशा } \\
\text { त्मता }\end{array}$ & पर्यायता & शब्दश्र्खला \\
\hline \\
पहिलो अनुच्छेद \\
$\begin{array}{l}\text { हामी जतिसुके } \\
\text { माथि उठौं, }\end{array}$
\end{tabular}




\begin{tabular}{|c|c|c|c|c|c|c|c|c|}
\hline र बादल बन्छौं, & - & - & हामी & र & - & बादल & - & बन्नु \\
\hline $\begin{array}{l}\text { हावाको इसारामा } \\
\text { यताउति दगुछों }\end{array}$ & - & - & हामी & - & - & हावा & - & दगुर्नु \\
\hline $\begin{array}{l}\text { र आफूलाई } \\
\text { गतिशील } \\
\text { भन्ठान्छौं }\end{array}$ & आफू & - & - & र & - & - & - & ठान्नु \\
\hline $\begin{array}{l}\text { अनि एक चोटि } \\
\text { माथि पुगेपछि, }\end{array}$ & - & - & - & - & - & - & - & - \\
\hline $\begin{array}{l}\text { हामी आफ्नो } \\
\text { धरतीलाई } \\
\text { विर्सन्छों }\end{array}$ & हामी & - & - & - & धरती & - & - & विर्सनु \\
\hline $\begin{array}{l}\text { र आफ्नो } \\
\text { धरतीलाई }\end{array}$ & आफ्नो & & & र & धरती & - & - & - \\
\hline खोलालाई & - & & आफ्नो & - & - & खोला & - & - \\
\hline $\begin{array}{l}\text { बगरलाई } \\
\text { उपेक्षापूर्वक }\end{array}$ & - & & आफ्नो & - & - & बगर & - & - \\
\hline पालिएका कुकुर & - & & हामी & - & कुकुर & & - & - \\
\hline $\begin{array}{l}\text { भयालबाट } \\
\text { गल्लीका } \\
\text { कुकुरहरूलाई } \\
\text { हेरेर भुकेभैं }\end{array}$ & - & - & - & - & कुकुर & - & - & - \\
\hline हामी भुक्तछौं & हामी & - & - & - & भुक्नु & - & - & भुक्नु \\
\hline $\begin{array}{l}\text { र आफ्ना } \\
\text { कुकुरभुकाइलाई } \\
\text { गर्जन भन्ठान्छौं }\end{array}$ & आफ्ना & - & - & र & $\begin{array}{l}\text { कुकुर } \\
\text { गर्जन }\end{array}$ & भुकाइ & - & - \\
\hline $\begin{array}{l}\text { अनि अन्त्यमा } \\
\text { एक दिन बर्सेर } \\
\text { चकनाचूर हुन्छौं }\end{array}$ & - & - & हामी & - & - & - & - & हुनु \\
\hline $\begin{array}{l}\text { र फेरि परिणत } \\
\text { हुन्छौं पानीका } \\
\text { थोपाहरूमा }\end{array}$ & - & - & हामी & र / फेरि & पानी & थोपा & - & - \\
\hline $\begin{array}{l}\text { निर्बलिया } \\
\text { थोपाहरूमा }\end{array}$ & - & - & - & - & - & थोपा & - & - \\
\hline र कुनै इनार, & - & - & - & र, वा & - & इनार, & - & - \\
\hline
\end{tabular}




\begin{tabular}{|c|c|c|c|c|c|c|c|c|}
\hline $\begin{array}{l}\text { खाडल वा } \\
\text { पोखरीमा }\end{array}$ & & & & & & $\begin{array}{l}\text { खाडल } \\
\text { पोखरी }\end{array}$ & & \\
\hline $\begin{array}{l}\text { कुहेर बिताउँछौों } \\
\text { बाँकी जीवन }\end{array}$ & - & - & - & - & जीवन & - & - & बिताउनु \\
\hline $\begin{array}{l}\text { टर्र... टर्र } \\
\text { टर्टराउने } \\
\text { घिनलागदा } \\
\text { भ्यागुताहरू } \\
\text { पालेर, }\end{array}$ & - & - & - & - & - & - & - & भ्यागुता \\
\hline $\begin{array}{l}\text { विष नभएका } \\
\text { साँपहरू अँगलेर } \\
\text { । }\end{array}$ & - & - & - & - & - & - & - & साँप \\
\hline $\begin{array}{l}\text { हामी जतिसुकै } \\
\text { माथि उठौं }\end{array}$ & हामी & - & - & जतिसुकै & - & - & - & - \\
\hline $\begin{array}{l}\text { जतिसुकै } \\
\text { यताउति दगुरौं }\end{array}$ & - & - & हामी & जतिसुकै & - & - & - & - \\
\hline $\begin{array}{l}\text { जतिसुकै ठूलो } \\
\text { स्वरमा गर्जों }\end{array}$ & - & - & हामी & जतिसुकै & - & - & - & - \\
\hline $\begin{array}{l}\text { तर, हामी } \\
\text { भित्र- भित्रै } \\
\text { खोक्रा छौं }\end{array}$ & हामी & - & - & तर & - & - & - & - \\
\hline $\begin{array}{l}\text { हाम्रो उठाइको } \\
\text { कुनै महत्त्व छैन, }\end{array}$ & हाम्रो & - & - & - & - & - & - & - \\
\hline $\begin{array}{l}\text { हाम्रो दगुराइको } \\
\text { कुनै लक्ष्य छैन, }\end{array}$ & हाम्रो & - & - & - & कुनै,छैन & - & - & - \\
\hline हाम्रो गर्जनको & हाम्रो & - & & - & गर्जन & & - & - \\
\hline $\begin{array}{l}\text { पानीमा } \\
\text { फालिएको } \\
\text { अगुल्टाको } \\
\text { 'छ्वाइयँ'भन्दा } \\
\text { बढ़ी वजन छैन । }\end{array}$ & - & - & हाम्रो & - & पानी & - & - & - \\
\hline $\begin{array}{l}\text { हामी बाहिरबाट } \\
\text { जतिसुकै उच्च } \\
\text { देखिए तापनि }\end{array}$ & - & - & - & $\begin{array}{l}\text { जतिसुकै } \\
\text { तापनि }\end{array}$ & उच्च & - & - & - \\
\hline
\end{tabular}




\begin{tabular}{|c|c|c|c|c|c|c|c|c|}
\hline $\begin{array}{l}\text { भित्रभित्रै निरन्तर } \\
\text { खिइंदै र घिसिंदै } \\
\text { गइरहेका छौं }\end{array}$ & - & - & हामी & र & - & - & - & - \\
\hline $\begin{array}{l}\text { हाम्रो बाहिरको } \\
\text { उँचाइ भूटा हो, }\end{array}$ & हाम्रो & - & - & - & उँचाइ & - & - & - \\
\hline भ्रम हो । & - & - & - & - & & - & - & - \\
\hline $\begin{array}{l}\text { अग्लो टाकुरामा } \\
\text { उम्रेको सानो } \\
\text { च्याउको } \\
\text { उँचाइभन्दा }\end{array}$ & - & - & - & - & उँचाइ & टाकुरा & अग्लो & - \\
\hline $\begin{array}{l}\text { यसको बर्ता } \\
\text { महत्त्व छैन }\end{array}$ & - & यसको & - & - & महत्त्व & - & - & - \\
\hline $\begin{array}{l}\text { वा दुइटा अग्ला } \\
\text { बाँस खुटामा } \\
\text { बाँधेर हिंड्ने }\end{array}$ & - & - & - & वा & - & - & अग्ला & खुट्टा \\
\hline $\begin{array}{l}\text { भारतीय } \\
\text { चटकेको } \\
\text { उँचाइभन्दा } \\
\text { यसको बढी } \\
\text { विशेषता छै,न, }\end{array}$ & - & यसको & - & - & उँचाइ & - & - & - \\
\hline $\begin{array}{l}\text { अग्लो चुच्चे } \\
\text { टोपी लगाई } \\
\text { नाच्ने }\end{array}$ & - & - & - & - & - & - & अग्लो & - \\
\hline $\begin{array}{l}\text { सर्कसको } \\
\text { जोकरको } \\
\text { उँचाइभन्दा } \\
\text { यसको वर्ता } \\
\text { महत्त्व छैन, }\end{array}$ & - & यसको & - & - & $\begin{array}{l}\text { उँचाइ } \\
\text { महत्त्व }\end{array}$ & - & - & - \\
\hline $\begin{array}{l}\text { हामी बाहिरको } \\
\text { उचाइमा रमेका } \\
\text { छौं, लट्टिएका छौं, } \\
\text { फुलेका छौं }\end{array}$ & हामी & - & - & - & उचाई & $\begin{array}{l}\text { रम्नु, } \\
\text { फुल्नु } \\
\text { लठ्ठिनु }\end{array}$ & - & - \\
\hline $\begin{array}{l}\text { तर हामीले } \\
\text { आफ्नो आस्थाको } \\
\text { द्विपमा }\end{array}$ & $\begin{array}{l}\text { हामी } \\
\text { आफ्ना }\end{array}$ & - & - & तर & - & द्विप & - & - \\
\hline
\end{tabular}




\begin{tabular}{|c|c|c|c|c|c|c|c|c|}
\hline $\begin{array}{l}\text { निरन्तर खिइंदै र } \\
\text { घिस्सिदै } \\
\text { गइरहेको } \\
\text { कुरालाई भुलेका } \\
\text { छौं }\end{array}$ & - & - & हामी & र & - & - & - & भुल्नु \\
\hline $\begin{array}{l}\text { हीनताको द्विपमा } \\
\text { पछारिएर }\end{array}$ & - & - & - & - & - & द्विप & - & पछारिनु \\
\hline $\begin{array}{l}\text { हामीले आफ्नो } \\
\text { पूर्वस्मृति } \\
\text { गुमाइसक्यौं }\end{array}$ & हामी & - & - & - & - & - & - & गुमाउनु \\
\hline $\begin{array}{l}\text { हामीले आफ्नो } \\
\text { विगत ऊँचाइलाई } \\
\text { विर्सिसक्यौं }\end{array}$ & हामी & - & - & - & उँचाइ & - & - & विर्सनु \\
\hline $\begin{array}{l}\text { हामीले } \\
\text { मानिसको } \\
\text { सामान्य } \\
\text { उँचाइलाई } \\
\text { विर्सिसक्यौं }\end{array}$ & हामी & - & - & - & उँचाइ & - & - & - \\
\hline $\begin{array}{l}\text { हामीले सामान्य } \\
\text { मानिसको } \\
\text { उँचाइलाई } \\
\text { बिर्सिसक्यौं }\end{array}$ & हामी & - & - & - & उँचाइ & - & - & - \\
\hline $\begin{array}{l}\text { त्यसैले जब कुनै } \\
\text { सामान्य मानिस }\end{array}$ & - & त्यसैले & - & - & - & - & - & - \\
\hline $\begin{array}{l}\text { कथामा वर्णित } \\
\text { 'गुलिभर' कैं, }\end{array}$ & - & - & - & - & - & - & - & - \\
\hline $\begin{array}{l}\text { आई पल्टन्छ } \\
\text { हाम्रो आस्थाको } \\
\text { द्विपमा }\end{array}$ & हाम्रो & - & - & - & - & द्विप & - & - \\
\hline $\begin{array}{l}\text { हामी छक्क परेर } \\
\text { उसलाई हेछों }\end{array}$ & हामी & - & - & - & - & - & - & - \\
\hline $\begin{array}{l}\text { हामी उसलाई } \\
\text { हेरेर छक्क पछौं }\end{array}$ & हामी & - & - & - & उसलाई & - & - & हेर्नु \\
\hline हामीलाई उसको & हामी & - & - & - & उँचाइ & - & - & लाग्नु \\
\hline
\end{tabular}




\begin{tabular}{|c|c|c|c|c|c|c|c|c|}
\hline $\begin{array}{l}\text { उँचाइ देखेर } \\
\text { आश्चर्य लाग्छ }\end{array}$ & & & & & & & & \\
\hline $\begin{array}{l}\text { हामीलाई आफ्नो } \\
\text { पुड्काइ देखेर } \\
\text { डर लाग्छ }\end{array}$ & हामी & - & - & - & देखेर & - & - & - \\
\hline $\begin{array}{l}\text { र त हामी } \\
\text { आफ्नो हीन } \\
\text { भावनाका }\end{array}$ & हामी & - & - & र & - & हीन & - & - \\
\hline $\begin{array}{l}\text { सियो जत्रा स- } \\
\text { साना } \\
\text { हतियारहरूको } \\
\text { उसमाथि }\end{array}$ & $\begin{array}{l}\text { उस } \\
\text { माथि }\end{array}$ & - & - & - & - & सियो & - & - \\
\hline प्रहार गछौं, & - & - & हामी & - & - & - & - & गर्नु \\
\hline $\begin{array}{l}\text { उसको अड्ग- } \\
\text { प्रत्यड्गमा चढ़छों, }\end{array}$ & उसको & - & - & - & - & - & - & चढ़नु \\
\hline उफ्रन्छौं, & - & - & हामी & - & - & - & - & उफ्रनु \\
\hline टोक्छौं, & - & - & हामी & - & - & - & - & टोक्नु \\
\hline चिमोट्छौं, & - & - & हामी & - & - & - & - & चिमट्नु \\
\hline $\begin{array}{l}\text { र अन्त्यमा } \\
\text { थकित भएर तल } \\
\text { ओर्लन्छों, }\end{array}$ & - & - & हामी & र & - & - & - & ओर्लनु \\
\hline शान्त हुन्छौं, & - & - & हामी & - & - & - & - & - \\
\hline समर्पित हुन्छौं & - & - & हामी & - & - & - & - & - \\
\hline $\begin{array}{l}\text { र कुनै ठूलो } \\
\text { चट्टानमाथि उर्लेर } \\
\text { समुद्रको छालले }\end{array}$ & - & - & - & र & - & समुद्र & - & - \\
\hline $\begin{array}{l}\text { तल ओर्लेर } \\
\text { त्यसको पाउ } \\
\text { पखालेकैं }\end{array}$ & - & त्यसको & - & - & - & - & - & पाउ \\
\hline $\begin{array}{l}\text { हामीले पुज्न } \\
\text { थाल्दछों त्यो } \\
\text { साधारण } \\
\text { मानवलाई }\end{array}$ & हामी & त्यो & - & - & पुज्न & - & - & - \\
\hline महान् भनेर । & - & - & - & - & - & - & - & - \\
\hline
\end{tabular}




\begin{tabular}{|c|c|c|c|c|c|c|c|c|}
\hline $\begin{array}{l}\text { हामी बाहिरबाट } \\
\text { जतिसुकै उच्च } \\
\text { देखिए तापनि }\end{array}$ & हामी & - & - & तापनि & - & - & उच्च & - \\
\hline $\begin{array}{l}\text { भित्रभित्रै खिइंदै } \\
\text { गइरहेका छौं }\end{array}$ & - & - & हामी & - & - & - & - & - \\
\hline $\begin{array}{l}\text { हामी } \\
\text { 'लिलिपुट'का } \\
\text { मानव हौं }\end{array}$ & हामी & - & - & - & - & - & - & - \\
\hline $\begin{array}{l}\text { हामी लघुमानव } \\
\text { हौं । }\end{array}$ & हामी & - & - & - & मानव & - & - & - \\
\hline \multicolumn{9}{|l|}{ तेस्रो अनुच्छेद } \\
\hline $\begin{array}{l}\text { हामी आफूखुसी } \\
\text { कहिल्यै मिल्न } \\
\text { नसक्ने }\end{array}$ & $\begin{array}{l}\text { हामी/ } \\
\text { आफू }\end{array}$ & - & - & - & - & - & - & नसक्ने \\
\hline $\begin{array}{l}\text { कसैले } \\
\text { मिलाइदिनुपर्ने, }\end{array}$ & - & - & हामी & - & - & - & - & - \\
\hline $\begin{array}{l}\text { हामी आफूखुसी } \\
\text { कहिले छुट्टिन } \\
\text { नसक्ने }\end{array}$ & $\begin{array}{l}\text { हामी, } \\
\text { आफू }\end{array}$ & - & - & - & - & - & - & - \\
\hline $\begin{array}{l}\text { कसैले } \\
\text { छुट्याइदिनुपर्ने, }\end{array}$ & - & - & हामी & - & - & - & - & - \\
\hline $\begin{array}{l}\text { हामी आफूखुसी } \\
\text { कहिले अगाडि } \\
\text { बढ़न नसक्ने }\end{array}$ & $\begin{array}{l}\text { हामी/ } \\
\text { आफू }\end{array}$ & - & - & - & - & - & - & नसक्नु \\
\hline $\begin{array}{l}\text { कसैले } \\
\text { पछाडिबाट } \\
\text { हिर्काउनुपर्ने, } \\
\text { हिंडाउनुपर्ने }\end{array}$ & - & - & हामी & - & - & - & - & - \\
\hline $\begin{array}{l}\text { हामी रझ्न- } \\
\text { रोगन छुटेका, } \\
\text { टुटेका, फुटेका }\end{array}$ & हामी & - & - & - & - & - & - & - \\
\hline $\begin{array}{l}\text { पुरानो } \\
\text { क्यारमबोर्डका } \\
\text { गोटी हौं }\end{array}$ & - & - & हामी & - & - & $\begin{array}{l}\text { क्यारेमबो- } \\
\text { ड }\end{array}$ & - & - \\
\hline
\end{tabular}




\begin{tabular}{|c|c|c|c|c|c|c|c|c|}
\hline $\begin{array}{l}\text { एउटा } \\
\text { मनोरञ्जन } \\
\text { खेलको सामग्री, }\end{array}$ & - & - & - & - & - & खेल & - & - \\
\hline $\begin{array}{l}\text { एउटा } \\
\text { खेलाडीमाथि } \\
\text { आश्रित, }\end{array}$ & - & - & हामी & - & - & खेलाडी & - & - \\
\hline $\begin{array}{l}\text { आफ्नो गति } \\
\text { हराएका }\end{array}$ & आफ्नो & - & - & - & - & - & - & - \\
\hline $\begin{array}{l}\text { एउटा } \\
\text { 'स्ट्राइकर'द्वारा } \\
\text { सन्चालित }\end{array}$ & - & - & हामी & - & - & स्ट्राइकर & - & - \\
\hline $\begin{array}{l}\text { हो, हामी मानिस } \\
\text { कम र बर्ता } \\
\text { गोटी हौं । }\end{array}$ & हामी & - & - & र & - & गोटी & - & - \\
\hline हामी वीर छौं & हामी & & - & - & वीर & - & - & - \\
\hline तर बुद्धू छौं & - & & हामी & - & बुद्धु & - & - & - \\
\hline हामी बुद्धू छौं & हामी & - & - & - & बुदु & - & - & - \\
\hline $\begin{array}{l}\text { र त हामी वीर } \\
\text { छों }\end{array}$ & हामी & - & - & - & वीर & - & - & - \\
\hline $\begin{array}{l}\text { हामी बुद्धू } \\
\text { नभइकन वीर } \\
\text { कहिले हुन सकैनैं } \\
:\end{array}$ & हामी & - & - & - & $\begin{array}{l}\text { वीर, } \\
\text { बुद्धु }\end{array}$ & - & - & - \\
\hline $\begin{array}{l}\text { हामी } \\
\text { महाभारतको } \\
\text { कथामा वर्णित } \\
\text { एकलव्य हौं }\end{array}$ & हामी & - & - & - & - & - & - & - \\
\hline $\begin{array}{l}\text { प्रत्येक पिंढीको } \\
\text { द्रोणाचार्यले } \\
\text { हामीलाई उपेक्षा } \\
\text { गई }\end{array}$ & - & - & हामी & - & - & - & - & - \\
\hline $\begin{array}{l}\text { हामीलाई } \\
\text { ज्ञानदान गर्नबाट } \\
\text { इन्कार गछ }\end{array}$ & हामी & - & - & - & ज्ञान & - & - & - \\
\hline
\end{tabular}




\begin{tabular}{|c|c|c|c|c|c|c|c|c|}
\hline $\begin{array}{l}\text { इन्कार गई } \\
\text { मान्न हाम्रो } \\
\text { योग्यतालाई, }\end{array}$ & हाम्रो & - & - & - & - & योग्यता & - & - \\
\hline शक्तिलाई, & - & - & हाम्रो & - & - & शक्ति & - & - \\
\hline र अस्तित्वलाई & - & - & हाम्रो & र & - & अस्तित्व & & \\
\hline $\begin{array}{l}\text { तर, हामी तिनै } \\
\text { द्रोणाचार्यको } \\
\text { मूर्ति बनाउँछों }\end{array}$ & हामी & - & - & तर & - & - & - & - \\
\hline $\begin{array}{l}\text { आफ्नो } \\
\text { भुप्रोअगाडि }\end{array}$ & आफ्नो & - & - & - & - & - & - & - \\
\hline त्यसलाई पुज्छौं & - & त्यसलाई & - & - & - & - & - & - \\
\hline ढोग्छौं । & - & & $\begin{array}{l}\text { त्यस- } \\
\text { लाई }\end{array}$ & - & - & - & - & - \\
\hline \multicolumn{9}{|l|}{ पाँचौ अनुछेद } \\
\hline $\begin{array}{l}\text { निरन्तर } \\
\text { धर्नुविद्याको } \\
\text { अभ्यास गछौं, }\end{array}$ & - & - & हामी & - & - & - & - & - \\
\hline $\begin{array}{l}\text { र द्रोणचार्यका } \\
\text { अन्य कुलीन }\end{array}$ & - & - & - & र & - & - & - & - \\
\hline $\begin{array}{l}\text { चेलाहरूभन्दा } \\
\text { बढी कुशलता } \\
\text { प्राप्त गछौं }\end{array}$ & - & - & हामी & - & - & - & - & - \\
\hline $\begin{array}{l}\text { तर हाम्रो } \\
\text { कुशलतादेखि } \\
\text { आश्चर्यचकित }\end{array}$ & हाम्रो & - & - & तर & - & - & - & - \\
\hline र भयभीत भई & - & - & & र & - & - & - & - \\
\hline $\begin{array}{l}\text { प्रत्येक पिंढीमा } \\
\text { द्रोणाचार्य } \\
\text { हामीकहाँ आउँछ }\end{array}$ & हामी & - & - & - & - & - & - & - \\
\hline $\begin{array}{l}\text { र गुरू दक्षिणा } \\
\text { माग्छ }\end{array}$ & - & - & हामी & - & - & गुरू & - & - \\
\hline $\begin{array}{l}\text { र हामी सहर्ष } \\
\text { उसको इशारामा }\end{array}$ & $\begin{array}{l}\text { हामी/ } \\
\text { उसको }\end{array}$ & - & - & र & - & - & - & - \\
\hline आफ्नो बुढीऔंलो & आफ्नो/ & - & - & - & - & भेटी & - & - \\
\hline
\end{tabular}




\begin{tabular}{|c|c|c|c|c|c|c|c|c|}
\hline $\begin{array}{l}\text { काटेर उसलाई } \\
\text { भेटी दिन्छौं, }\end{array}$ & उसलाई & & & & & & & \\
\hline $\begin{array}{l}\text { आफ्नो अस्तित्व } \\
\text { मेटेर उसलाई } \\
\text { समर्पित गछों }\end{array}$ & $\begin{array}{l}\text { आफ्नो/ } \\
\text { उसलाई }\end{array}$ & - & - & - & - & - & - & - \\
\hline $\begin{array}{l}\text { र मख्ख पछौं } \\
\text { आप्नो } \\
\text { गुरूभक्तिमाथि }\end{array}$ & आफ्नो & - & - & र & - & - & - & - \\
\hline $\begin{array}{l}\text { आप्नो } \\
\text { आत्मशक्तिमाथि }\end{array}$ & आफ्नो & - & - & - & - & - & - & - \\
\hline $\begin{array}{l}\text { त्यसैले हामी वीर } \\
\text { छौं }\end{array}$ & हामी & त्यसैले & - & - & वीर & - & - & - \\
\hline तर, बुद्धू छौं & - & - & हामी & तर & - & - & - & - \\
\hline $\begin{array}{l}\text { र त हामी वीर } \\
\text { छों }\end{array}$ & हामी & - & - & र & वीर & - & - & - \\
\hline $\begin{array}{l}\text { हामी बुद्धू } \\
\text { नभइकन वीर } \\
\text { कहिले हुन } \\
\text { सकेनौ }\end{array}$ & हामी & - & - & - & वीर & - & - & - \\
\hline $\begin{array}{l}\text { हामी कसैको } \\
\text { मूर्ति थापना } \\
\text { नगरीकन }\end{array}$ & हामी & - & - & - & - & - & - & - \\
\hline $\begin{array}{l}\text { वीर कहिले हुन } \\
\text { सकेनौं । }\end{array}$ & - & - & - & - & वीर & - & - & - \\
\hline हामी पैताला हौं & हामी & - & - & - & पैताला & - & - & - \\
\hline केबल पैताला & - & - & - & - & पैताला & - & - & - \\
\hline र फगत पैताला & - & - & - & र & पैताला & - & - & - \\
\hline $\begin{array}{l}\text { पैताला : उसको } \\
\text { भरमा शरीर } \\
\text { उभिन्छ }\end{array}$ & उसको & - & - & - & पैताला & भर & - & - \\
\hline $\begin{array}{l}\text { पैताला : जसको } \\
\text { आधारमा शरीर } \\
\text { हिड्छ }\end{array}$ & - & जसको & - & - & $\begin{array}{l}\text { पैताला } \\
\text { शरीर }\end{array}$ & आधार & - & - \\
\hline पैताला : जसको & - & जसको & - & - & पैताला & भरोसा & - & - \\
\hline
\end{tabular}




\begin{tabular}{|c|c|c|c|c|c|c|c|c|}
\hline $\begin{array}{l}\text { भरोसामा शरीर } \\
\text { दगुईछ }\end{array}$ & & & & & शरीर & & & \\
\hline $\begin{array}{l}\text { पैताला ? तर जो } \\
\text { भन्ठान्छ कि }\end{array}$ & - & जो & - & तर & पैताला & - & - & - \\
\hline $\begin{array}{l}\text { शरीररले कृपा } \\
\text { गरेर उसलाई } \\
\text { पालिरहेछ }\end{array}$ & उसलाई & - & - & - & शरीर & - & - & - \\
\hline $\begin{array}{l}\text { दया गरेर } \\
\text { उसलाई सँग } \\
\text { सँग हिंडाइरहेछ, }\end{array}$ & उसलाई & - & - & - & - & - & - & - \\
\hline $\begin{array}{l}\text { मख्व पई } \\
\text { शरीरको } \\
\text { महानता माथि }\end{array}$ & - & - & - & - & शरीर & - & - & - \\
\hline $\begin{array}{l}\text { र सँधै सम्पूर्ण } \\
\text { शरीरको भार } \\
\text { सहन्छ }\end{array}$ & - & - & - & र & शरीर & - & - & - \\
\hline $\begin{array}{l}\text { कहिले शिर } \\
\text { उचालेर माथि } \\
\text { हेर्देन }\end{array}$ & - & - & - & - & - & - & - & शिर \\
\hline $\begin{array}{l}\text { संधै संधै } \\
\text { नतमस्तक रहन्छ, }\end{array}$ & - & - & - & - & & - & - & मस्तक \\
\hline हामी पैताला हौं & हामी & - & - & - & पैताला & - & - & - \\
\hline $\begin{array}{l}\text { हामी दौडमा } \\
\text { प्रथम हुन्छौों }\end{array}$ & हामी & & & - & दौड & - & - & - \\
\hline $\begin{array}{l}\text { र हाम्रो निधारले } \\
\text { टिका थाप्छ, }\end{array}$ & हाम्रो & - & - & र & सम्मान & टिका & - & निधार \\
\hline $\begin{array}{l}\text { हामी दौडमा } \\
\text { प्रथम हुन्छौं }\end{array}$ & हामी & - & - & - & दौड & & - & - \\
\hline $\begin{array}{l}\text { र हाम्रो घाँटीले } \\
\text { माला लाउँछ }\end{array}$ & हाम्रो & & - & र & & माला & - & घाँटी \\
\hline $\begin{array}{l}\text { हामी दौडमा } \\
\text { प्रथम हुन्छों }\end{array}$ & हामी & - & - & - & दौड & - & - & - \\
\hline $\begin{array}{l}\text { र हाम्रो छातीले } \\
\text { तक्मा टाँस्छ }\end{array}$ & हाम्रो & - & - & र & & तक्मा & - & छाती \\
\hline
\end{tabular}




\begin{tabular}{|c|c|c|c|c|c|c|c|c|}
\hline $\begin{array}{l}\text { हाम्रो टिका थाप्ने } \\
\text { निधार अर्के छ, }\end{array}$ & हाम्रो & - & - & - & - & टिका & - & निधार \\
\hline $\begin{array}{l}\text { हाम्रो माला } \\
\text { लाउँने घाँटी } \\
\text { अर्के छ, }\end{array}$ & हाम्रो & - & - & - & - & माला & - & घाँटी \\
\hline $\begin{array}{l}\text { हाम्रो तक्मा } \\
\text { टाँस्ने छाती अर्के } \\
\text { छ, }\end{array}$ & हाम्रो & - & - & - & - & - & - & छाती \\
\hline $\begin{array}{l}\text { हामी फगत } \\
\text { कसैको इसारामा }\end{array}$ & हामी & - & - & - & - & - & - & - \\
\hline $\begin{array}{l}\text { टेक्ने, हिड्ने र } \\
\text { दगुर्ने पैताला हौं }\end{array}$ & - & - & हामी & र & पैताला & - & - & - \\
\hline केबल पैताला & - & - & हामी & - & पैताला & - & - & - \\
\hline $\begin{array}{l}\text { र फगत पैताला } \\
\text { । }\end{array}$ & - & - & - & र & पैताला & - & - & - \\
\hline \multicolumn{9}{|l|}{ सातौं अनुच्छेद } \\
\hline $\begin{array}{l}\text { हामी केही पनि } \\
\text { ह्वैनौं }\end{array}$ & हामी & - & - & पनि & - & - & - & - \\
\hline $\begin{array}{l}\text { र शायद त्यसैले } \\
\text { केही ह्वौं कि }\end{array}$ & - & त्यसैले & हामी & र & - & - & - & - \\
\hline $\begin{array}{l}\text { हामी कतै पनि, } \\
\text { केही पनि छैनौं }\end{array}$ & हामी & - & - & पनि & - & - & - & - \\
\hline $\begin{array}{l}\text { र शायद त्यसैले } \\
\text { कतै, केही छों } \\
\text { कि }\end{array}$ & - & त्यसैले & हामी & र & - & - & - & - \\
\hline $\begin{array}{l}\text { हामी बाँचिरहेका } \\
\text { छैनौं }\end{array}$ & - & - & - & - & - & & - & - \\
\hline $\begin{array}{l}\text { तर शायद } \\
\text { त्यसैले पो } \\
\text { बाँचेका छों कि }\end{array}$ & - & त्यसैले & हामी & तर & - & - & - & - \\
\hline $\begin{array}{l}\text { त्यसैले आओ ए } \\
\text { शून्य पूजकहरू }\end{array}$ & - & त्यसैले & - & - & पूजक & - & - & - \\
\hline $\begin{array}{l}\text { हामी सब मिलेर } \\
\text { पुजौं यो }\end{array}$ & हामी & - & - & - & शून्यता & - & - & - \\
\hline
\end{tabular}




\begin{tabular}{|l|l|l|l|l|l|l|l|l|}
\hline शून्यतालाई & & & & & & & & \\
\hline $\begin{array}{l}\text { हामी सब मिलेर } \\
\text { ढोगौं यो } \\
\text { रिक्ततालाई }\end{array}$ & हामी & - & - & - & - & रिक्तित & - & - \\
\hline $\begin{array}{l}\text { हाम्रो अस्तित्वको } \\
\text { यो देवतालाई । }\end{array}$ & हाम्रो & यो & - & - & - & - & - & - \\
\hline
\end{tabular}

प्रस्तुत तालिकाका आधारमा कविताको विश्लेषण निम्नानुसार गर्न सकिन्छ :

\section{निदर्शन}

प्रस्तुत सङ्कथनमा सम्बोधक 'म' लोप अवस्थामा आई सम्बोधित हामी, आफू, आफ्नो, हाम्रो तथा विषयका रूपमा सम्बोधित ऊ, उसको, उसलाई जस्ता सन्दर्भवन्दुका माध्यमबाट हामी नेपालीको पराधीन मानसिकता र कार्यका कारण दासत्ववत् जीवन बिताइरहेको वर्तमान अकर्मण्य सोच र वृत्तिलाई सन्दर्भित भएका छन्। कविताको पहिलो अनुच्छेदमा हाम्रो वर्तमान मानसिकताले हामीलाई वजनहीन, अस्तित्वहीन, शक्तिहीन र पराधीन तुल्याएको सन्दर्भीकृत गर्ने निदर्शन/सन्दर्भन कोटिको प्रयोग भएको छ। पहिलो अनुच्छेदका विभिन्न पड्किक्ति आएका हामी/हाम्रो निदर्शनले हाम्रो वर्तमान सोच, चाल, प्रवृत्ति, गतिविधि, व्यवहार, जीवनपद्धति आदि स्वतन्त्र जीवनचेतनाबाट विमुख भइसकेको वर्तमान नेपालीको प्रवृत्तिलाई आकाशबाट बर्सने निर्बलियो र अस्तित्वहीन पानीको थोपो, सारहीन जीवन बाँचेको भ्यागुतो, फोहोर पानीमा बस्ने सर्प, भुस्याहा कुकुरको जति अस्तित्व नभएको पाल्तु कुकुर जस्ता सन्दर्भलाई पानीमा फालेको अगुल्टोको भन्दा पनि निम्नस्तरको भइसकेको सन्दर्भसँग सम्पृक्त गरेको छ।

कविताको दोस्रो अनुच्छेदमा पहिलो सूचनालाई निरन्तरता दिन ऊ, उसको जस्ता सन्दर्भविन्दुको प्रयोग भएको छ। अर्काको संस्कृतिलाई ग्रहण गरिसकेको हाम्रो पराधीन सोच र गिरिसकेको साखलाई सन्दर्भीकृत गरेका यी सन्दर्भविन्दुले पहाड जस्तो उच्च विरासतलाई पहाडले आफूमाथि उम्रिएको च्याउलाई महान् ठानेर स्वयंलाई आत्मसमर्पणवादी तुल्याई गौरवपूर्ण अर्काको इसारामा नाच्ने कठपुतली र जोकर बनेको, अर्थसँग जोडेको छ भने पहिलो अनुच्छेदमा अभिव्यक्त आफ्नो पहिचान गुमाएका नेपालीको वास्तविकताद्योतक अर्थबीच समानान्तरता सम्बन्ध स्थापित गरेको छ। तेस्रो अनुच्छेदमा समाख्याताले सम्बोधित हामी तथा आफू/आफ्नो निदर्शनका माध्यमबाट हामी विवेक र चेतनाहीन भई आफ्नो वास्तविकतालाई बिर्सेर अर्काको स्वार्थलाई सर्वश्व ठानी बाँच्न आफ्नो स्वाधीनतालाई परिहार गरी एउटा खेलाडीको मनोरज्जक खेलको सामग्रीमा परिणत भइसकेको मूलसन्दर्भभित्र एकता, भाइचारा र अपनत्वको भावबाट विमुख भएको नेपाली समाजमा खण्डित भएको राष्ट्रियता र आततायी संस्कृतिलाई अबलम्बन गरेका समाजका नेतृत्वकर्ताको बहकाइमा लागेर क्षताविक्षत र अवमूल्यन बनेको सन्दर्भलाई सन्दर्भीकृत गरेको छ। कविताको चौथो अनुच्छेदमा आएका हामी/हाम्रो/आफ्नो निदर्शनले अघिल्ला तीन अनुच्छेदमा आएका भावसन्दर्भको संयोजनका क्रममा हामी पराधीनप्रिय भएको सन्दर्भलाई हाम्रो विगतको गौरवपूर्ण पूर्वसूचनासँग जोडेको छ। पाँचौं अनुच्छेद चौथो अनुच्छेदकै भावसन्दर्भलाई निरन्तरता दिंदै हामी कसरी पराधीन भएका छौं तथा हामीमाथि कसरी शोषण भएको छ भन्ने सन्दर्भको खोलुवाका रूपमा आएको छ। यस अनुच्छेदमा आएको हामी/हाम्रो, आफ्नो/उसको/उसलाई निदर्शनले हाम्रो निस्वार्थ सोकोपनलाई द्रोणाचार्य प्रभृति कुशल कुटनीतिजले सम्मोहन वृत्तिका अन्तरसाक्ष्यमा आफ्नो स्वार्थपूर्तिका लागि प्रयोग गरी हाम्रो क्षमता, कुशलता 
र दक्षतालाई अपाहिज तुल्याउँछ् भन्ने सन्दर्भलाई पूर्वापर विषयक्रमसँग जोडेको छ। छैठौं अनुच्छेदमा हामी/हाम्रो निदर्शकको प्रयोग भएको छ। हाम्रो अस्तित्वहीन भौतिक/सामाजिक अवस्था र पराधीन मानसिकताका कारण द्रोणाचार्य प्रभृति बाह्य र समाजको नेतृत्वकर्ताको भूमिकामा रहेका सामन्तको शोषण, दमन र विभेदलाई स्वीकार गरी तिनको विचारधारा स्वीकारी नतमस्तक बनेको, हाम्रो श्रममाथि शोषण र विभेद हुँदा, हामीमाथि दासवत् व्यवहार गरिंदा प्रतिकार नगरेको, वीरताको गौरवशाली इतिहास खुम्चिएर सीमित सामन्तको रौरवका सामु नतमस्तक बनेको, हाम्रो मानसिकतामा विद्रोहका स्थानमा आत्मसमर्पणप्रियता जब्बर भएर बसेको सन्दर्भलाई आर्थी एकत्वमा सम्पृक्त गराएको छ। सातौं अनुच्छेदमा सास फेर्नु, चलायमान हुनु वा आफ्नो गतिविधि देखाउनु मात्र अस्तित्वको परिसूचक होइन, अस्तित्वशाली हुनुको तात्पर्य समाजमा स्वतन्त्र पहिचान हुनु पनि हो तसर्थ हाम्रो वर्तमान सड्कटमा परेको अस्तित्व बोकेर हिंडिरहेको छ। यसबाट पार्थक्य लिई समाजमा मान्छेलाई दासवत् व्यवहार गर्ने विचारधारा र पद्धतिलाई परास्त गरी यस्ता कुपित प्रवृत्तिका विरूद्ध सङ्घर्ष गरी हाम्रो विगतको समृद्ध स्वाधीनतालाई स्थापित गर्न वर्तमानमा देखिएको रिक्तता र पराबलम्बी मनोभावले सृजना गरेको शून्यतालाई भड़न गर्नुपर्ने सन्दर्भलाई सङ्केत गर्न हामी निदर्शकको प्रयोग भएको छ।

\section{प्रतिस्थापन}

प्रस्तुत हामी कवितामा प्रतिस्थापक एकाइको न्यून मात्रामा प्रयोग भएको छ। कविताको पहिलो अनुच्छेदमा कुनै प्रतिस्थापक एकाइको प्रयोग भएको छैन भने दोस्रो अनुच्छेदको छैठौं पड्किमा आएको यसको प्रतिस्थापकले अघिल्ला पाँच पड्किमा आएका विविध सन्दर्भलाई प्रतिस्थापन गरी परवर्ती सन्दर्भसँग सम्पृक्त गराएको छ। आठौं पड्किको यसको प्रतिस्थापकले भारतीय चटकेको भ्रमित उचाइ तथा दसौं पड्किको यसको प्रतिस्थापकले सर्कसको जोकरको उचाइ पदावलीलाई प्रतिस्थापन गरेको छ। उन्नाईसौं पड़क्तिको त्यसैले प्रतिस्थापकले हामीले हाम्रो गौरवमय विगत, सम्भ्रान्त वर्तमान र सुनौलो आगतलाई बिर्सिएर पराधीन बन्दै गएको सन्दर्भलाई प्रतिस्थापित गरेको छ। सैतीसौं पड्तिक्ति आएको त्यसको प्रतिस्थापकले हाम्रो वैचारिक, मानसिक विचलन र स्वलनका कारण पराधीन बनेको मानसिकता र त्यसले स्वीकार गरेको दासत्वको सोचलाई प्रतिस्थापन गरेको छ भने अड्तीसौं पड्किको त्यो प्रतिस्थापकले दासत्वबोधलाई अभ्यन्तरण गरेको हाम्रो मानसिकताले सामान्यलाई असामान्यधारण ठानेको सन्दर्भलाई प्रतिस्थापित गरेको छ।

चौथो अनुच्छेदको चौंधौं र पन्ध्रौं पड्क्तिमा आएको त्यसलाई प्रतिस्थापकले अनुच्छेदका पूर्ववर्ती तेह्र पड्तिमा आएको द्रोणाचार्य प्रभृति सोच र कर्मलाई स्वीकार गरेको हाम्रो मानसिक र व्यवहारिक अवस्थाको सूचना दिई त्यस्ता वृत्ति देखाएर शोषण गर्न बानी परेका अभिवृत्तिको शिकार भएको सन्दर्भलाई प्रतिस्थापन गरेको छ। पाँचौं अनुच्छेदको तेह्रौं पड्किमा प्रयोग भएको त्यसैले प्रतिस्थापकले अनुच्छेदमा आएका अघिल्ला बाह्न पड्किमा रहेको अर्थसन्दर्भलाई प्रतिस्थापित गरेको छ। छैठौं अनुच्छेदको पाँचौं/छैठौं पड्किको जसले तथा सातौं पड्किको जो प्रतिस्थापकले पैंताला शब्दलाई प्रतिस्थापन गरी शब्द र अर्थगत साहचर्यलाई सम्पृक्त गराएको छ। कविताको अन्तिम तथा सातौं अनुच्छेदको दोस्रो पड्क्तिको त्यसैले प्रतिस्थापकले अस्तित्वहीनताका बीच हामी जीवित रहेको, चौथो पड्किक्ति त्यसैले प्रतिस्थापकले कहीं कतै नभएर पनि अस्तित्वमा रहेको, छैठौंको त्यसैले प्रतिस्थापकले हामी शून्य जीवन बाँचिरहेको, सातौं पड्किको त्यसले प्रतिस्थापकले जडचेतनायुक्त चाल देखाएर जीवित हाम्रो प्रवृत्ति तथा दसौं पड्किको यो प्रतिस्थापकले कविताका सबै अनुच्छेद र पड्क्तिमा विद्यमान रहेको 
हाम्रो अकर्मण्य दासवत् प्रवृत्तिको सारलाई प्रतिस्थापित गरी परिवेश, सन्दर्भ र अर्थगत साहचर्यलाई निरन्तरता दिई सुसम्बद्ध पाठ निर्माण गरेको छ।

\section{लोप}

प्रस्तुत कवितामा हामी निदर्शकको लोप बढी भएको छ भने तेहौं र चौधौं पड्किक्ति आफ्नो विशेषण लोप भएको छ, । यसैगरी पन्ध्रौं, उन्नाईसौं, बीसौं र अठ्ठाईसौं पड्क्तिमा हामी लोप भएको छ भने तेत्तीसौं पड्क्तिमा हाम्रो लोप भएको छ। दोस्रो अनुच्छेदको दोस्रो, बाहौं, तीसौं, एकतीसौं, बत्तीसौं, चौंतीसौं र चालीसौं पड्क्तिमा निजवाचक हामी निदर्शकको लोप भएको छ। तेस्रो अनुच्छेदको दोस्रो, चौथो, छैठौं, आठौं, दसौं र बाह्रौं पड़क्तिमा हामी सर्वनाम लोप भएको छ। चौथो अनुच्छेदको दोस्रो, सातौं, र पन्द्रौं पड्क्तिमा हामी तथा दसौं र एघारौं पड्कि्ति हाम्रो भेदक विशेषण लोप भएको छ। पाँचौं अनुच्छेदको पहिलो, तेस्रो, सातौं र चौधौं पड्क्तिमा सम्बोधित हामी लोप भएको छ भने छैठौं अनुच्छेदको छब्बीसौं पड्किमा हामी सर्वनाम लोप भएको छ। सृजनाका ऋममा लोप भएका निदर्शकले काव्यिक सड्कथनको परिवेश, सन्दर्भ तथा अर्थगत सूचनालाई निरन्तर रूपमा अध्याहारबाट निरन्तर सूचना शुखला निर्माण गर्न अहम् भूमिका खेलेको छ।

\section{संयोजन}

यस कविताको पहिलो अनुच्छेदको पहिलो, दोस्रो र तेस्रो पड्किको जतिसुकैले हाम्रो अर्थहीन चाल र गतिविधिलाई संयोजन गरेको छ भने चौथो पड्किको विरोधसूचक तरले अघिल्ला तीन पड्किमा अभिव्यक्त हाम्रो मूल्यहीन गतिविधिलाई पछिल्लोवाक्यसँग जोडेको छ। सातौं पड़क्तिको कारणवाचक रले छैठौं र सातौं पड्किलाई परस्परमा जोडेको छ। नवौं र बाह्रौं पड्किको रले कमश: दुई वाक्य, अठारौं पड्क्तिको रले दुई वाक्य, बीसौं पड्क्तिको रले दुई पड्क्तिलाई, यही पड्क्तिको फेरि स्थानापन्नीय संयोजकले हाम्रो दासवत् अभिवृत्तिद्योतक अर्थहीन सन्दर्भलाई नियमित सूचनामा जोडेको छ। बाईसौं पड्किमा आएको रले एक्काईसौं पड्क्तिमा आएको पूर्वसूचनालाई पश्चसूचनासँग, तथा यही पड्क्तिको विकल्पवाचक वा संयोजकले स्थानबोधक शब्दलाई परस्परमा जोडेको छ। कविताको पहिलो-तेस्रो पड्किको पुनरावृत्ति भएको छब्बीसौं-अठ्ठाईसौं पड्क्तिको जतिसुकैले पूर्वापर सन्दर्भका अन्तरसाक्ष्यमा हाम्रो वर्तमान प्रवृत्तिलाई जोडेको छ भने उनन्तीसौं पड़क्तिको तरले अघिल्ला पड्किलिाई पछिल्लो पड्किसंग जोडी सूचनाप्रवाहलाई निरन्तरता दिएको छ। दोस्रो अनुच्छेदको पहिलो पड्किमा आएको जतिसुकैले वर्तमानमा हामीसंग नभएको सूचना सन्दर्भलाई सड्केत गरेको छ भने यही पड्किको व्यतिरेकवाचक तापनिले दुई वाक्यलाई परस्परमा जोडेको छ। दोस्रो पड्क्तिको रले दुई शब्दलाई, सातौं पङ्क्तिको वाले दुई पड्किलाई, बाह्रौं पड्किको तरले अघिल्ला तीन र पछिल्लो एक वाक्यलाई, तेह्रौं पड्किको रले दुई शब्दलाई, छब्बीसौं पड्किको रले दुई पड्क्तिलाई, तेत्तीसौं पड्क्तिको रले अघिल्ला तीन र पछिल्ला तीन वाक्यलाई, छत्तीसौं पड्किको रले अघिल्ला तीन र पछिल्लो एक तथा चालीसौं पड्किको जतिसुकैले दुई पदावली बीचको परिणाम एवं तापनिले चार वाक्यलाई परस्परमा जोडी सुसम्बद्ध पाठ निर्माणमा अहम् भूमिका खेलेको छ।

कविताको तेस्रो अनुच्छेदको तेह्रों पड़क्तिमा आएको र संयोजकले दुई शब्दलाई जोडेको छ। चौथो अनुच्छेदको एघारौं पड्किको र ले अघिल्ला दुई वाक्यलाई पछिल्लो वाक्यसँग जोडेको छ भने बाह्रौं पड्किको तरले पछिल्ला तीन वाक्यलाई अघिल्लो सन्दर्भसंग जोडेको छ। पाँचौं अनुच्छेदको दोस्रो पड्क्तिको रले पहिलो र दोस्रो पड्क्तिका वाक्यलाई, चौथो पड्किको तरले तेस्रो र चौथो पड्कित्ति तथा पाँचौं पड्किक्ति रले चौथो र पाँचौं पड्क्तिलाई परस्परमा जोडेको छ। आठौं पड़क्तिको रले सातौं, आठौौ र नवौंपड्क्तिलाई जोडेको छ भने एघारौं 
पड्क्तिको रले दसौं र एघारौं, चौधौं पड्क्तिको तरले तेह्रों र चौधौं तथा पन्ध्रौं पड्क्तिको रले चौंधौं र पन्ध्रौं पड्किलाई परस्परमा जोडेको छ। छैठौं अनुच्छेदको तेस्रो पड्किको रले दुई पदावलीलाई, सातौं पड्क्तिको तरले शब्द र पदावलीलाई, एघारौं पड़क्तिको रले दुई पड्कित्रिा आएका वाक्यलाई, सोह्नौं अठारौं र बीसौं पड्किको रले दुई वाक्यलाई तथा पच्चीसौं र सत्ताईसौं पड़क्तिको रले ऋमश: दुई पदावलीलाई जोडेको छ। सातौं अनुच्छेदको पहिलो पड्तिक्ति पनि व्यतिरेकवाचक संयोजकले हामी केही नरहेको सन्दर्भलाई, दोस्रो पड्किको रले पहिलो र दोस्रो पड्कि, तेस्रोको पनि ... पनि ले दुई शब्दलाई, चौथोको रले दुई पड्कि तथा छैठौं पड्किको तरले दुई पझ्तिका वाक्यलाई जोडेको छ।

\section{पुनरावृत्ति}

प्रस्तुत कविताको पहिलो अनुच्छेदमा हाम्रो वर्तमानलाई बोध गराउने तथा हाम्रो सड्कटापन्न अस्तित्वको सूचक पानीको थोपाको रूपमा परिभाषित शब्द पहिलो अनुच्छेदको चौथो पड़क्तबाट आरम्भ भई तेत्तिसौं पड्क्त्कसम्म विस्तारित रही पाठगत संसक्तता सृजना गरेको छ। सूर्यद्वारा शोषित, हावाद्वारा सन्चालित हुने, वजन र सारहीन हाम्रो जीवनपद्धतिको सन्दर्भलाई पानीका निर्बलिया थोपासँग तुलना गरी जीवनपद्धतिको क्षयीकरण भएको सन्दर्भसँग जोडेको छ भने हाम्रो दीनहीन परिस्थितिगत सन्दर्भसँगको संसक्ति स्थापित गर्न पन्ध्रौं पड्क्त्देखि अठारौं पडिक्तसम्म मानवेतर प्राणी कुकुर, सरीसृप पुनरावृत्ति भई नेपालीको दीनहीन परिस्थितिलाई सान्दर्भीकृत गरेको छ। कविताको दोस्रो अनुच्छेदमा नेपालीको पराधीनप्रियताले कमजोर तुल्याएको भौतिक र मानसिक उचाइको अवस्थितिलाई बोध गराउने “उँचाइ’ शब्दको पुनरावृत्ति भएको छ। यस अनुच्छेदको पहिलो पडिक्तदेखि त्रिचालीसौं पडिक्तसमम्म विस्तारित संरचनामा हाम्रो जीवनको वास्तविकता अग्लो टाकुरामा उम्रिएको च्याउले आफूलाई अग्लो ठाने भैँ दिगभ्रमित र सारविहीन रहेको, हाम्रो आफ्नो गरिमा चटके वा जोकरभन्दा हेय र तुच्छ रहेको, हामी अन्तर्राष्ट्रिय मानचित्रमा आफ्नो स्वाभिमानलाई बेची आत्मसमर्पणवादी भइसकेको विदेशी शक्तिको यशोगानमा लागेको, तिनको उपस्थितिका सामू निरिह बनेको तथा आफ्नो सार्वभौम मानसिकता अर्कालाई बेचेर लघुमानवमा रूपान्तरित भएको सन्दर्भलाई पुष्टि गर्दे अवास्तविक उचाइलाई उच्च व्यक्तित्वमा परिभाषित गरी भ्रमित हाम्रो परिवेशलाई सन्दर्भसँग जोडेको छ।

तेस्रो अनुच्छेदमा हाम्रो विगतदेखि आगतसम्मको परम्परामा स्वाधीनताका नाममा पराधीन मनोभावना रहेको भावसन्दर्भलाई मनोरज्जक खेलको गोटीसँग तुलना गरी हाम्रो परनिर्भताको बढ़दो ऋमप्रति व्यड्ग्य गरिएको सन्दर्भसँग सम्पृक्त गराएको छ। चौथो अनुच्छेदमा इतिहासका साक्ष्यमा आफूलाई वर्तमानको परिवर्तनतर्फ मोड्न नसक्दा हाम्रा कमीकमजोरीहरू यथावत् रहेको भावलाई सन्दर्भसँग जोडेको छ। विगतमा विश्वले दिएको स्वाभिमान र वीरताको चर्चालाई आफ्नो गौरव ठान्ने क्रममा हाम्रो सोकोपन र वीरताको लिलामी गरी अर्काको प्रशंसा पाएर मौन बस्ने तथा जीवन धान्न बानी परेको अकर्मण्य हाम्रो वास्तविकताकै कारण पटकपटक उपेक्षित बन्दा पनि चेतना नखुलेको आजको अवस्थालाई वीर र बुद्युको पुनरावृत्ति अनुच्छेदको पहिलोदेखि तेत्तिसौं पडिक्तसमम्म वितरित रही संसक्ति सम्बन्व स्थापित गरेको छ।

कविताको पाँचौ अनुच्छेदमा पैंताला शब्दको पुनरावृत्ति भएको छ। हाम्रो आजको अवस्था पैंतालाको रहेको, पैंताला शरीरको सबैभन्दा उपेक्षित अङ्गका रूपमा रहेको, मूल सन्दर्भका रूपमा समाजमा व्याप्त रहेको शोषणवृत्तिलाई आत्मासाथ गरेका हामी शासकीय वृत्तिका सामु नतमस्तक रहेको सन्दर्भलाई पैंताला, पैंतालाको भूमिका र योगदान, कार्य र परनिर्भरताका माध्यमबाट हाम्रो परिवेशलाई प्रस्तुत गरेको छ। यस अनुच्छेदको 
पहिलोदेखि अठ्ठाईसौं पड़िक्तसम्म वितरित पैंताला शब्दको आवृत्तिले अनुच्छेद संरचनालाई सुगठित तुल्याइएको छ । कविताको अन्तिम अनुच्छेदमा पराधीन बनेको हाम्रो जीवनचेतना/जीवनपद्धति सुसुप्त अवस्थामा पुगेको अर्थ संवहन गर्ने हामी केही नभएको, कतै नभएको, शून्यतामा बाँच्न र रिक्ततालाई पुज्न बानी परेको अर्थ दिने शब्द र पदावलीको पुनरावृत्ति भएको छ। यस पुनरावृत्तिले वर्तमानमा सारहीन जीवन बाँचेको हाम्रो अवस्थालाई बुकाउने भाव, पराधीन बनेको हाम्रो परिवेशलाई सन्दर्भसँग जोडी संसक्ति सम्बन्ध स्थापित गरेको छ।

\section{समानार्थकता / पर्यायता}

प्रस्तुत कविताको पहिलो अनुच्छेदमा प्रयोग भएको महत्त्व र लक्ष्य शब्दले हाम्रो वर्तमान स्वाभिमान र प्रगति निराधार बन्दे गएको उपसन्दर्भलाई मूल सन्दर्भसँग सम्पृक्त गराएको छ। दोस्रो अनुच्छेदमा आएको उच्च शब्दका समानार्थी शब्दहरू अग्लो र उचाइ शब्दले आजको हाम्रो वजनहीन अवस्थालाई बोध गराएको छ। यसै अनुच्छेदको उत्तरार्द्धमा आएका चटके/जोकर जस्ता शब्दले हाम्रो कठपुतली अवस्थालाई सन्दर्भसँग अन्वय गराएको छ भने हामीले गुमाएको पूर्वस्मृति र विगतको समृद्ध परम्परालाई सूचित गर्ने शब्दका माध्यमबाट हामी खिइंदै गएको तथा हामी आकार, प्रकार, सोच, व्यवहार र चित्तवृत्तिकै तहमा स्खलित बनिसकेको सन्दर्भलाई सङ्केत गरेको छ। हामी व्यवहारिक रूपले नै रड्गहीन भइसकेको अर्थ पक्षलाई बोध गराउने क्यारेमबोर्डका गोटी जस्ता भएको सन्दर्भको पुष्टिका लागि टुटेका/फुटेका/छुटेका समानार्थी शब्द प्रयोग भएको तेस्रो अनुच्छेदमा कसैको आश्रयदाताका रूपमा स्थापित बनेको हाम्रो पहिचान आज पराश्रित बनेको परिवेशद्योतक कृपा- दया शब्दका माध्यमबाट प्रस्तुत भएको छ। चौथो अनुच्छेदमा हाम्रो पराधीन मानसिकताको उत्कर्षलाई बोध गराउन उपेक्षा- इन्कार, पुज्नु- ढोग्नु, योग्यता-कुशलता, भेटी-समर्पण आदि समानार्थक शब्दको प्रयोगले सन्दर्भगत संसक्ति सृजना गरेको छ। पाँचौं अनुच्छेदमा भर-आधार-भरोशा समानार्थी शब्दले आधारविहीन संस्कृतिको निर्माण गरी आफ्नो शिरजस्तो उच्च संस्कृतिलाई पाइताला जस्तो पराश्रित र दमित तुल्याइ आफूले गरेको कार्यको श्रेय आफैंले लिन नसक्ने दीनहीन जीवन बाँचिरहेको वस्तुसत्यलाई पुष्टि गरेको छ। कविताको अन्तिम अनुच्छेदमा आफ्नो समग्र अस्तित्व गुमाएको आजको नेपाली मानसिकताले शून्यता र रिक्तता मात्र अनुभूति गर्ने परिवेशका माध्यमबाट पाठगत अर्थलाई एकान्विति प्रदान गरेको छ। कविताका विभिन्न अनुच्छेदमा आएका समानार्थी शब्दको प्रयोगले प्रस्तुत काव्यिक सङ्कथनलाई सुसम्बद्ध पाठ तुल्याउनका लागि अहम् भूमिका खेलेका छन् ।

\section{शब्दशृझ्खला}

कविताको पहिलो अनुच्छेदमा हाम्रो वर्तमान अवस्थालाई पानीको थोपासँग तुलना गरी हाम्रो मूल्यहीन सन्दर्भलाई प्रस्तुत गरेका छन्। पानीको अस्तित्वहीन थोपाका रूपमा परिभाषित रहेको हाम्रो वर्तमान स्वयं आफ्नो वास्तविकताभन्दा भिन्न रहेको आप्नो गरिमा समाप्त भएको सन्दर्भ पानीका निर्बलीय थोपासम्बद्ध शब्दशृड्खलामार्फत् प्रस्तुत भएको छ। हाम्रो अस्तित्वहीन सन्दर्भलाई पानी निर्माण हुने वस्तुजगत्सम्बद्ध सूर्य, बादल, हावा, धरती, खोला, बगर, इनार, पोखरी जस्ता शब्दमा अन्तर्निहित आर्थी सम्बन्ध भएका शब्द शृड्खलाका माध्ययमबाट संसक्ति सम्बद्धता स्थापित भएको छ। दोस्रो अनुच्छेदमा उचाइ र आकारसँग सम्बन्धित शब्दश्ड़्खलाका रूपमा आएका शब्द र पदावलीको शृड्खलाका माध्यमबाट वर्तमानसम्बद्ध पहाडमा उम्रेको अस्तित्वहीन च्याउ, चटके, जोकर जस्ता आर्थी सम्बन्ध भएका शब्दको शृड्खलाका माध्ययमबाट अनुच्छेदको पूर्वार्द्ध अर्थ र सन्दर्भबीच संसक्ति सम्बन्धलाई प्रस्तुत गरेका छन्। अनुच्छेदको उत्तरार्द्धमा हाम्रो वर्तमान आकारलाई 
लघुतावाची शब्दश्ड्खलाका ओर्लेर, पुड्काई, हीन भावना, स- साना हतियार, ठूलो चट्टान माथि उर्लेर, समुन्द्रको छालले ओर्लेर पाउ पखालेकैं, साधारण मानवलाई महान् मानेर पुज्ने, लघुमानव जस्ता पद/पदावलीशृड्खलाले संसक्ति सम्बन्ध सृजना गरेको छ।

चौथो अनुच्छेदमा इतिहासलाई वर्तमानीकरण गरी आफ्नो सार्वभौम अभिवृत्तिका लागि विश्वमा पहिचान बनाएको हाम्रो छवि परनिर्भरताका कारण धाराशायी बन्दै गएको, हाम्रो वीरता बेचिएको, हामीले स्वयंलाई चिन्न नसकेको, अर्काको उपेक्षालाई प्रशंसा ठानेर बाँच्न अभ्यस्त बनेको, आफ्नो गौरव र शानलाई अक्षुण्ण राख्न नसकेको, बाह्य शक्तिसमक्ष आत्मसमर्पण गरी आफ्नो पहिचान गुमाएको सन्दर्भलाई वीर, बुद्धु, एकलब्य, द्रोणाचार्य जस्ता शब्दशृड्खलामा समावेश भएका विभिन्न उपसन्दर्भमा जोडिएर आएका उपेक्षा, इन्कार, योग्यता, शक्ति, अस्तित्व, कुशलता, जस्ता अर्थसम्बन्धयुक्त शब्दश्ड्खलामार्फत् प्रस्तुत भएको छ। कविताको पाँचौं अनुच्छेदमा मानवअड्रसम्बद्ध शब्दश्ड्ख्यलाका माध्यमबाट अनुच्छेदगत संसक्ति स्थापित भएको छ। अनुच्छेदको पहिलो पड्किमा पाइतालाबाट सुरू भएको शृड्खला अन्तिम पड़क्तिसम्म वितरित रहेको छ। यस शब्दशृड्खलामा मानव शरीर र अड्गसम्बद्ध : शिर, निधार, बूढीऔंला, घाँटी, छाती, पाइताला जस्ता शब्दको प्रयोग र तिनको आवृत्तिले सन्दर्भलाई परस्परमा जोडेको छ भने पाठगत संरचनालाई संशक्त तुल्याएको छ। कविताको अन्तिम तथा छैठौं अनुच्छेदमा कविताका पूर्वपर अनुच्छेदमा आएका सन्दर्भलाई संशक्त गराउने हाम्रो अस्तित्वहीनतासम्बद्ध हामी केही हौं वा होइनौंका बीचको संदिग्धता, हामी जिउँदो वा मरेका छौं बीचको संशय, हाम्रो अस्तित्वविहीन जीवनलाई पुष्टि गर्ने हाम्रो रिक्तता, शून्यता तथा हाम्रो परनिर्भरताबोधक पुज्ने, ढोग्ने तथा पराश्रित मानसिकतासूचक शब्दको सहचार्यका माध्यमले सिड्रो काव्यिक सङ्कथनको सार वा निष्कर्षलाई अन्तिम अनुच्छेदभित्र समावेश गरी भाव, परिवेश र सन्दर्भगत एकान्वितिको संश्लेषित स्वरूप प्रस्तुत भएको छ। उपर्युक्त शाब्दी शृड्खलाका अतिरिक्त मानवीय गतिविधिद्योतक क्रियामूल भएका विभिन्न अनुच्छेदमा आएका उठ्नु, दगुर्नु, गर्जनु, उचालिनु, ठान्नु, बिर्सनु, भुक्नु, हुनु, बिताउनु, भुल्नु, पछारिनु, गुमाउनु, हेर्नु, लाग्नु, गर्नु, चढ़नु, उफ्रनु, टोक्नु, चिमट्नु, ओर्लनु, नसक्नु आदि शब्दको सर्वसमावेशकारी शब्दको प्रयोगले कवितामा आन्तरिक सम्बद्धता सृजना गरेको छ।

\section{निष्कर्ष}

प्रस्तुत कवितामा समकालीन नेपाली परिवेशभित्र आम नेपाली मानसिकतामा स्थापित रहेको पराधीन सोच र अकर्मण्य अभिवृत्तिमूलक मूलसन्दर्भसँग सम्बन्धित विभिन्न सहायक सन्दर्भको सृजना गरी संसक्ति सम्बद्धता निर्माण भएको छ। संसक्ति व्यवस्था सड्कथन विश्लेषणअन्तर्गतको एउटा समालोचना पद्धति रहेको छ जसले पाठमा आएका शब्दले निर्माण गर्ने परिवेश तथा तिनको अर्थ र सन्दर्भबीचको अन्वयका आधारमा पाठगत सुसम्बद्धताको खोजी गर्दछ। कवितामा निदर्शनका माध्यमबाट कविताका प्रत्येक अनुच्छेद र पड्कितीच निरन्तर भावप्रवाह भई एकत्वपूर्ण पाठको सृजना भएको छ। प्रतिस्थापन र लोपको उचित व्यवस्था भएको यस कवितामा संयोजनले शब्दशब्द, शब्द-पदावली, पदावली-वाक्य तथा सन्दर्भ-सन्दर्भबीच अन्वय गराई सन्दर्भ र आर्थी अभिवृत्तिलाई संगठित र सुसम्बद्ध तुल्याएको छ। पुनरावृत्ति भएका शब्दको आवृत्तिले पाठका सन्दर्भशृड्खलालाई एकान्वित तुल्याई संरचनागत सुसम्बद्धता सृजना गरेको छ। कविताका विभिन्न सन्दर्भमा आएका पर्यायवाची र समावेशात्मक शब्दले पाठीय सन्दभलाईसंगठित तुल्याएको छ। यस काव्यिक सङ्कथनभित्र आएका विविध आर्थीसंरचना भएका शृड्खलाले कवितामा रहेका भाव, अर्थ, परिवेश र सन्दर्भलाई एकत्वपूर्ण प्रवाहमा जोडी व्यवस्थित र सुसम्बद्ध पाठका रूपमा कवितालाई संशक्त तुल्याउन अहम् भूमिका खेलेका छन्। समष्टिमा प्रस्तुत कविता व्याकरणिक र 
कोशीय संसक्ति सम्बन्धले पहिलो अनुच्छेददेखि अन्तिम अनुच्छेदसम्मका प्रत्येक पड्कि, सन्दर्भ र आर्थी सम्बन्धलाई संगठित गरी सशक्त, सुसम्बद्ध र संसक्त पाठमा रूपान्तरण गरेको निष्कर्ष हुनआउँछ।

\section{सन्दर्भसामग्री}

एटम. नेत्र. (२०७४). संक्षिप्त साहित्यिक शब्दकोश नेपाल प्रज्ञा प्रतिष्ठान ।

गौतम. देवीप्रसाद. (२०६६). सङ्कथन विश्लेषण. रत्न बृहत् नेपाली समालोचना सैद्धान्तिक खण्ड. सम्पा. राजेन्द्र सुवेदी र लक्ष्मणप्रसाद गौतम. रत्न पुस्तक भण्डार. पृ. पै१-५९१ ।

भट्टराई. भरतकुमार. (२०७१). सङ्कथन संरचना र संसक्ति व्यवस्था. वाङ्मय. पूर्णाड़-१५. पृ. ४७-४६इ।

यादव. योगेन्द्रप्रसाद र भीमनारायण रेगमी. (२०५९). भाषाविज्ञान. (दो.संस्क.) न्यू हिरा बुक्स इन्टरप्राइजेज ।

शेरचन. भूपि. (२०७४). घुम्ने मेचमाथि अन्धो मान्छे. (पन्द्रौं संस्क.) साका प्रकाशन ।

Flowerdew. John. (2008). Cohesion. 'Discourse in English Language Education'. Taylor and Francis Group.

Halliday.MAK.and Ruqaiya Hasan. 1976. Cohesion in English. Longman Group Limited. Hoey. Michel. 1991a. Patterns of Lexis in Text.Oxford University Press.

Tanskanen.Aapo. 2006. Collaborating towards Coherance. Linguist List Vol.18. 